\title{
Adolescence and Perinatally - Acquired HIV: The case to improve sexual and reproductive healthcare for female adolescents in Malawi
}

\author{
Mwalabu $\mathrm{G}^{1 *}$, Manjanja $\mathrm{V}^{2}$ and Mwallabu $^{2}$ \\ ${ }^{1}$ Department of Medical and Surgical Nursing, University of Malawi, Lilongwe, Malawi \\ ${ }^{2}$ Department of Midwifery, University of Malawi, Malawi \\ ${ }^{3}$ Programme Manager, Health Commission, Evangelical Association of Malawi, Malawi
}

Submission: December 18, 2017; Published: February 20, 2018

*Corresponding author: Gertrude Mwalabu, Department of Medical and Surgical Nursing, University Lecturer, University of Malawi, Malawi; Email: mwalabugees2004@kcn.unima.mw

Keywords: Reproductive health; Female adolescents; Sexual relationships; Economic opportunities; Culturally embedded; HIV

Abbreviations: SRH: Sexual and Reproductive Health; HIV: Human Immunodeficiency Virus; NSO: National Statistical Office

\section{Introduction}

With an escalating numbers of children with perinatallyacquired HIV surviving to adolescence and becoming sexually active, the need for age-appropriate support regarding sex and relationships is increasing. Several studies have shown that female adolescents are particularly more prone to engaging in sexual behaviors to meet their daily survival needs [1-3]. This result in poor sexual and reproductive health (SRH) outcomes as most adolescents are reported having little control over negotiating safer sex or contraception. The HIV management services in Malawi provide significant support for the adolescents' HIV-related clinical needs, but still encounter unprecedented challenges of meeting the SRH needs of this growing population as they grow into adulthood.

Globally over two million adolescents aged 10-15, and five million youths aged 15-24 are living with HIV [4]. In Malawi, out of an overall population of over 17 million, almost $8.8 \%$ people are living with HIV [5]. Approximately $10 \%$ of those living with HIV are children and young people with over $90 \%$ of the children acquiring the HIV acquired perinatally [6]. HIV prevalence is higher among young women than young men $(4.9 \%$ versus $1 \%$ ) [5]. Several studies reported that female adolescents with perinatally acquired HIV are also becoming sexually active at an early age than their male counterparts for different reasons [7]. Socio-economic factors, service provision and service providers are key in shaping the adolescents' sexual experiences and these factors will be the main focus of this review. Gender and power relation issues continue to be reflected as the overarching theme across the body of knowledge.

\section{Struggling to earn a living, reality of growing up HIV and consequences for sexual health}

Majority of female adolescents with perinatally-acquired HIV have lost one or both parents and live with foster families, which increases their likelihood to live in poverty [8]. In this milieu, sexual activities are often employed as means of survival or as an economic strategy for idealized lifestyle or modernity. However, this becomes complicated in the context of HIV positive status, in which tension exists between the young women's sexual needs and the economic and social realities/expectations and HIV prevention issues including status disclosure to sexual partners. A growing body of qualitative studies has shown that inferior socio-economic status, lack of bargaining power in sexual relationships coupled with gender power inequality (in terms of experience, authority, and control over sexual activity) affect the female adolescents' ability to take informed decisions particularly on safer sex and contraception [9].

Most sexual relationships were with older and married men. The male relationships and economic dependence on men diminished adolescents' autonomy on sexual issues as it gave their older partners positions of power and control in sexual encounters. This increased the likelihood for the adolescents to submit to unsafe practices such as unprotected sex as a surety 


\section{Global Journal of Reproductive Medicine}

against abandonment and to maintain their sources of financial support. Hence, protecting themselves and others became less likely and this increases their vulnerability even when they had access to appropriate information. These issues continue to pose a challenge to HIV services on how best to meet the female adolescents' SRH needs [10,11].

\section{Cultural silence: A response to adolescent SRH needs}

While challenges on discussing sexual issues with young people are well documented elsewhere $[12,13]$. similarly in Malawi premarital sex and parent-child discussion on sexual issues is culturally forbidden for the fear of influencing young people to initiate sex too early or because sexual discussions are customarily held in secret within families [14]. In this context, research shows that it becomes a challenge for the majority of young people to access contraceptives offered by adults as they might not want to be seen as not conforming to cultural and social norms [9]. Likewise, several studies in Africa have also shown that service providers and counsellors advise young people living with perinatally acquired HIV to abstain from sexual activities but the adolescents desire otherwise [15].

Health professionals might be conforming to cultural norms of not talking directly about sexual issues with young people by providing understated warnings about the possible adverse outcomes of sex rather than practical SRH education, advice and support. Furthermore, most HIV management services are predominantly organised around pediatric and adult care rather than adolescent care. This means that young people who no longer fit under pediatric services and who feel uncomfortable with adult services lack programs that address their unique needs. Possibly the assumption made is that perinatally HIV infected adolescents are not and should not be sexually active despite their sexual needs. However, the desire to have children in the future and/or continue having children despite knowledge of the risks associated with childbearing and resistance from others in the community remains strong among the female adolescents [16]. For instance, the number of teenage pregnancies among perinatally HIV infected female adolescents is a signal that service providers in most countries still face challenges in their HIV and AIDS management and the efforts on prevention as the patterns are indicative of poor preventive practices.

In Malawi, culturally, childbearing is of utmost significance to both men and women, and is valued as a mark of womanhood/ femininity and masculinity, to maintain sexual relationships or to meet societal expectations, hence promoting their self-worth and avoiding societal reproach. This prevailing construction of femininity limits the agency of the female adolescents growing up with HIV to demand for their SRH rights like consistent and proper use of condoms. For instance, empirical data in HIV management centers in Malawi have similar experiences of teenage pregnancies among adolescents with perinatallyacquired HIV. This clearly indicates that living with HIV does not considerably influence young women's attitudes towards sex and child bearing, hence they indulge in risky sexual practices like their HIV negative counterparts. Therefore, care providers' knowledge of socio-demographic factors inspiring female adolescents' desires for childbearing is imperative for sexual risk reduction counseling and reproductive care.

\section{Conclusion and Recommendation}

This review highlights the complexity of trying to implement SRH services for female adolescents living with perinatallyacquired HIV in a resource constrained and conservative society. HIV care in Africa including Malawi seems still not effectively prepared to deal with adolescents' complex SRH issues [17]. Cultural normative expectations seem to locate service providers at a critical intersection between cultural and social values which promote sexual abstinence until marriage, and the reality of young women's premarital sex and desire to use contraceptives. Improving SRH information, advice, support and access to contraceptives for female adolescents living with perinatally acquired HIV can be undertaken through relatively modest service innovations and staff training. It is therefore significant that service providers need to network and collaborate with influential community, traditional and religious leaders to gain their support in enhancing community awareness on cultural issues that impact on female adolescents.

There is need to identify positive aspects of the cultural normative expectations relative to HIV infection rather than solely blaming the culture for failing to promote optimal SRH outcomes. Leaders need to be trained on how to change the culturally embedded dominating power relations and reinforce young women's awareness of their SRH rights to enable them oppose gender power imbalances, exercise agency and allow them make decisions regarding their SRH. Policymakers and NGOs need to be aware of young women's material needs, and get involved in empowering these young women with stable income generating activities or sources of income (not handouts). Thus, without empowerment on resource mobilization, guaranteed condom access alone is inadequate to reduce their risks for poor SRH outcomes. Economic opportunities through small scale businesses, academic and vocational achievements can give female adolescents a position of power to desist being vulnerable and foster their ability to exercise agency and become resilient.

\section{Authors' contributions}

GM wrote the mini review with input from all authors. All authors did the literature search, read and approved the final review.

\section{References}

1. Mwalabu G, Catrin E, Redsell S (2017) Factors influencing the experience of sexual and reproductive healthcare for female adolescents with perinatally-acquired HIV: a qualitative case study. BMC Womens Health 17(1): 125.

2. Busza J, Besana GV, Mapunda P, Oliveras E (2013) "'I have grown up controlling myself a lot.' Fear and misconceptions about sex among 


\section{Global Journal of Reproductive Medicine}

adolescents vertically-infected with HIV in Tanzania". Reprod Health Matters 21(41): 87-96.

3. Hodgson I, Ross J, Haamujompa C, Gitau-Mburu D (2015) Living as an adolescent with HIV in Zambia -- lived experiences, sexual health and reproductive needs. AIDS Care 24(10): 1204-1210.

4. Dick B, Ferguson BJ (2015) Health for the World's Adolescents: A Second Chance in the Second Decade, J Adolesc Health 56(1): 306.

5. National Statistical Office (NSO) \& ICF Macro (2016) Malawi Demographic and Health Survey 2015-16," NSO and ICF Macro and Calverton, Maryland, Zomba, Malawi, USA.

6. National AIDS Commission (2009) Malawi HIV prevention strategy (2009-2013). Lilongwe, Malawi: National AIDS Commission, Africa.

7. Lowenthal ED, Bakeera-Kitaka S, Marukutira T, Chapman J, Goldrath $\mathrm{K}$, et al. (2014). Perinatally acquired HIV infection in adolescents from sub-Saharan Africa: a review of emerging challenges. Lancet Infect Dis 14(7): 627-639.

8. Evans R, Becker S (2009) Children Caring for Parents with HIV and AIDS: Global Issues and Policy Responses. Policy Press.

9. Obare F, Birungi H Kavuma L (2011) Barriers to Sexual and Reproductive Health Programming for Adolescents Living with HIV in Uganda. Population Research and Policy Review 30(1): 151-163.

10. Ross J, Cataldo F (2010) Adolescents living with HIV in low-income settings: A review of the evidence on gaps in HIV services. International HIV/AIDS Alliance, pp. 1.
11. WHO (2008) UNICEF, Scale up of HIV-related prevention, diagnosis, care and treatment for infants and children: A Programming Framework.

12. Bastien S, Kajula L, Muhwezi W (2011) A review of studies of parentchild communication about sexuality and HIV/AIDS in sub-Saharan Africa. Reprod Health 8: 25.

13. Close K (2010) Psychosocial aspects of HIV/AIDS: Children and Adolescents, in HIV Curriculum for the health professional, Baylor International Paediatric AIDS Initiative, Baylor College of Medicine, USA.

14. Wittenberg J, Munthali A, Moore A, Zulu E, Madise N, et al. (2007) Protecting the Next Generation in Malawi: New Evidence on Adolescent Sexual and Reproductive Health Needs. Protecting the Next Generation, Switzerland.

15. Birungi H, Mugisha J, Obare F, Nyombi J [2017] Sexual Behavior and Desires Among Adolescents Perinatally Infected with Human Immunodeficiency Virus in Uganda: Implications for Programming ScienceDirect.

16. Obare F, Van der Kwaak (2010) HIV positive adolescents in Kenya Access to sexual and reproductive health services, Amsterdam: KIT Publishers, Netherlands.

17. WHO (2012) Making health services adolescent friendly: Developing national quality standards for adolescent-friendly health services. Switzerland, Geneva.

Your next submission with Juniper Publishers
will reach you the below assets
- Quality Editorial service
- Swift Peer Review
- Reprints availability
- E-prints Service
- Manuscript Podcast for convenient understanding
- Global attainment for your research
- Manuscript accessibility in different formats
( Pdf, E-pub, Full Text, Audio)
- Unceasing customer service
Track the below URL for one-step submission
https://juniperpublishers.com/online-submission.php

